\title{
Determinant of Smartphone Purchase Intention of the Office Staffs in the North of Vietnam
}

\author{
Dieu Tra Nguyen $\mathrm{Thi}^{{ }^{*}} \quad$ Shih-Wei Wu ${ }^{1} \quad$ Thi Thom Hoang ${ }^{2}$ \\ 1.Department of Business Management, National Taipei University of Technology, Taiwan \\ 2.Department of Electrical \& Electronics, Nha Trang University, Vietnam
}

\begin{abstract}
Nowadays, smartphone is one of the most popular mobile devices to make calls and send texts. Moreover, you can use smartphone to take pictures with high quality, listen music or play video. This study investigates the relationship between product quality, price, design, features, band name and purchase intention of a smart phone. To do so, a survey was conducted by distributing 250 questionnaires in some of different offices in North of Vietnam. The Pearson Correlation was applied for the data analysis. The results show that there is a positive and significant relationship among product quality, price, design, features, band name and purchase intention. Based on these results, it seems that the smart phone company needs to develop marketing strategy to increase purchase intention of office staffs.
\end{abstract}

Keywords: smartphone, purchase intention, office staff, in the North of Vietnam

DOI: $10.7176 /$ RJFA/11-24-02

Publication date: December $31^{\text {st }} 2020$

\section{Introduction}

A mobile communication device is basically designed to convey traditional voice between two individuals, sending text messaging and executing basic functions, nevertheless cell phone had undergone numerous transformations, making its functionalities increasing tremendously against time resulted from the changing needs of cell phone subscribers (Kushchu, 2007; Hakoama and Hakoyama, 2011).

Nowadays, consumers no longer view smartphones just as devices for calling and texting, instead as multiuse devices for gaming, socializing, and downloading applications which results in a radical shift in behaviour patterns. A survey done by Ericsson, 2014 reported that smartphones adoption is predicted to increase dramatically during the coming years with smartphone subscriptions growing by almost five times between 2013 and 2019 which will result in an excess of 700 million smartphone subscriptions in the South East Asia and Oceania.

According to Dodds and Monroe (1985), purchase intention is a behavior tendency of a customer who is intended to purchase a product. Previous studies and researches stated that purchase intention is an important indicator of actual purchase behavior. Farquhar (1989) stated that product quality is essential for developing a positive evaluation of a product or brand in customer's memory.

Laroche et al. (2005) investigated that product design is an important part for the evaluation of products in the emerging economies and country image of a specific product can impact the product beliefs and product evaluations of customers. Ag rdi and Bauer (2000) stated that a low price is a future goal in which a customer is willing to select a kind of smartphone. Oulasvirta et al. (2011) investigated that the feature is an important variable for products which is positively related with consumers' intention to purchase the mobile phones.

The main objective of this research is to determine the significant influence of brand name, product features, qualify, price and image on the demand for smartphones among office staffs in the North of Vietnam. The obtained results can be used as a good reference source for the business or smartphone manufacturers in the North of Vietnam to increase the sale of their products.

\section{Literature Review}

In this chapter, the definitions of some factors (independent variables) and the factor (dependent variable) are defined. The independent variables include price, brand, design, quality, and feature, whereas the dependent variable is defined as purchase intention.

\subsection{Purchase intention}

Whitlark, Geurts and Swenson (1993) defined purchase intention as a purchase probability associated with an intention category at the percentage of individuals that will actually buy product. Ghosh (1990) stated that purchase intention is an effective tool used in predicting purchasing process. Once the consumers decide to purchase the product in a certain store, they will drive by their intention. However, purchase intention might alter by the influence of price, quality perception and value perception (Zeithaml, 1988) and Grewal et al (1998). In addition, consumers will interrupt by internal impulse and external environment during the purchasing process. Their behavior will drive by the physiological motivation that stimulates their respond and then bring them to the retail store to fulfill their need (Kim and Jin, 2001). 
Besides that, purchase intention is the implied promise to one's self to buy the product again whenever one makes the next trip to the market (Fandos \& Flavian, 2006; Halim \& Hameed, 2005) and depicts the impression of customer retention. Furthermore, previous studies (Pi et al., 2011; Pavlou and Gefen, 2004) have found that purchase intention plays a role as a key factor that really influences consumers' actual buying behavior and transaction activities in the future as well.

\subsection{Product design}

Knight and Calantone (2000) defined that product design is the consumer's perception of stimulus cues, and which will collective in the mind of consumer. Keller (1993) also stated that product design is a perception of customers towards the products which is reflected by the experience or imagination in consumer memory. Aaker and John (1989) defined that product design is how a product is perceived by consumers and which comes into customers' memories.

\subsection{Price}

Price is the cost that consumers can best determine, and thus plays an important role in their decision. For example, in a recent study of consumers' selection of an outlet at which to make a purchase, price was consistently stated as a major influencing factor. Such a finding is consistent with the feelings of retailers themselves, who indicate price is an important selection criterion for consumers (Ag rdi and Bauer, 2000).

\subsection{Product feature}

Nowadays, there are many high technology features of smartphones in the market. Thus, different people will choose different features of smartphones that can meet with their needs and desires. According to Oulasvirta et al. (2011), smartphones nowadays are being featured with wireless connectivity, a built-in web browser, application installation, full programmability, a file management system, multimedia presentation and capture, high-resolution displays, several gigabytes of storage and location as well as movement sensors. Based on previous research, there are five design characteristics of mobile phone being preferred by consumers such as camera, color screen, voiceactivated dialing, internet browsing and wireless connectivity (Ling et al., 2006). Based on study done by similar researcher indicates that the respondents that mostly office staffs prefer to purchase mobile phone due to its physical appearance, size and menu organization.

Product features can be defined as the attributes of a product that can satisfy consumers' preferences through having the product, using and applying the product (Kotler \& Armstrong, 2007). According to Lay-Yee et al (2013), hardware is the surface of device that can be physically touched such as body of the smartphone, size, weight, color as well design. Meanwhile, software includes computer programs, procedure and documentation. In addition, operating platform, storage or application also can be categorized as software. There are several types of operating software such as iOS, Android, Windows, RIM Blackberry, Symbian, Bada and maemo. Hardware and software can be categorized as product features. Based on previous research conducted by Russell (2012), consumers in Vietnam mostly prefer Android consists of $41 \%$, followed by IOS with $18 \%$, RIM Blackberry and Windows recorded the same with 6\%. The users in the other countries such as Singapore, Australia, New Zealand, Thailand and Malaysia mostly use Android operating system. Based on previous done by Lay-Yee et al (2013), 31\% of users prefer software compare to hardware only $17.6 \%$. This indicates consumers will look more on software rather than hardware in purchase the smartphone.

\subsection{Product quality}

Product quality is the evaluation of consumer's current consumption experience upon overall excellence of products (Baker and Crompton (2000)). Aaker and Gray (1982) also stated that product quality is the consumers' perception of the superiority or overall quality of a service or product with respect to its intended purpose. According to Zeithaml (1988), product quality refers to the customers' expectations and judgments about the performance of products. Consumers consider high-quality products to be reliable, durable, and easy to maintain. For business markets, technical suitability, ease of repair, and company reputation are important characteristics. Unlike consumers, most organizations place for less emphasis on price than on product quality. One important dimension is consistency. Consistency of quality refers to the degree to which a product has the same level of quality over time. Consistency means giving consumers the quality they expect every time they purchase the product.

\subsection{Brand}

"A brand is a name, term, sign, symbol, or design or combination of them, intended to identify the goods and services of one seller or group of sellers and to differentiate them from those of the competitor." (Kotler, 1967). Organizations will always find ways to differentiate them from the others especially in smartphone industry that keep always changing the technology. The organizations have to find new technology that not available in the 
market and meet demand the customers. Brand name can be an identity and exclusivity that represent the organization. Brand name can be as name, term, symbol and design to differentiate the organization from the competitors. According to Cornelis (2010), most of organizations emphasize about brand name that can be as an invaluable asset to their products and services. This can be the competitive advantage to the organization.

\section{Methodology}

This section introduces some main analyses applied in this study. Firstly, the one-way ANOVA was used to test how different groups of gender, age, marital status, and income affect or do not affect purchase intention. Secondly, the reliability analysis (Cronbach's Alpha) is applied to test the internal consistency of the variables in a factor. Finally, correlation analysis is implemented to discover the relationship between five independent variables (price, brand, design, quality, feature) with the dependent variable (purchase intention). For this, the data acquisition for data preprocessing is mentioned first.

\subsection{Data Acquisition}

This study uses both types of data collection method which are primary and secondary data. This study used survey questionnaire as the primary data source by using questionnaire, while in the secondary data collection is from journal, articles, internet, text book, media publications, electronic library database and article. Therefore, in this research, 250 sets of questionnaire were distributed to office staffs in North of Vietnam. The target population is the collection of the elements or objects that possess the information the researcher is seeking for (Malhotra and Peterson, 2006).

\subsection{Data Analysis Technique}

Statistical Package for Social Science 20.0 (SPSS) is use to analyze the data that collected from respondents.

\subsubsection{Descriptive analysis}

Descriptive data is obtained in this research to describe characteristics of the observed data and summary as a statistic. Usually, data is represented as a graphic form (Hair et al., 2009). In this study, we used the demographic characteristic of respondents (office staffs in the North of Vietnam), including gender, age, marital status, and income.

\subsubsection{Reliability Analysis Cronbach's Alpha}

Cronbach's Alpha is the most common measures of internal consistency, which is usually believed to indicate the degree to which a set of items measures a single one-dimensional latent construct. In this study, we used Cronbach's Alpha coefficient to analysis reliability of the factors.

\subsubsection{Correlation analysis}

Correlation analysis helps the researchers to measure the linear relationship between two variables. The value for correlation can fall between -1 and +1 . The value of +1 means the value of one variable increases, leading the remaining variable also increases. The value of -1 means the value of one variable decreases, leading the remaining variable also decreases. The value of 0 means there is no correlation between the variables. Values between 0 and 0.3 ( 0 and -0.3 ) indicate a weak positive (negative) linear relationship via a shaky linear rule. Values between 0.3 and 0.7 (0.3 and -0.7) indicate a moderate positive (negative) linear relationship via a fuzzy-firm linear rule. Values between 0.7 and 1.0 (-0.7 and -1.0) indicate a strong positive (negative) linear relationship via a firm linear rule. The value of $r$ squared is known as the proportion of variance in one variable accounted for by the other variable. In this research, using correlation analysis to discover correlation between five independent variables (price, brand, design, quality, feature) with the dependent variable (purchase intention).

\section{Researchh Results \& Discuss}

According to Sekaran (2003), the objectives of data analysis are getting a feel for the data (descriptive analysis), testing the goodness of the data (reliability test) and testing the hypotheses develop for the research (correlation analysis).

\subsection{Respondents' demographic and purchase intention}

The demographic characteristics of respondents are depicted in Table 1. Based on gender background, 63.8\% of the respondents are male, whereas the percentage of female respondents is $36.2 \%$. The majority of the respondents fall in the age group of $22-30$ years old which recorded at $46.6 \%$, followed by $34.4 \%$ for the age level from 30 to 40 , whereas reached at $12.9 \%$ for the age of $40-50$ years old, and finally only $6.1 \%$ of respondents with the age above 50 . 
Table 1. Demographic characteristics

\begin{tabular}{ccc}
\hline & F & Sig. \\
\hline Gender & 4.132 & .044 \\
Age & 2.992 & .033 \\
Marital status & 4.067 & .045 \\
Income & 3.744 & .012 \\
\hline
\end{tabular}

It can be seen from Table 1, all of the sig levels is lower than 0.05 . This means the gender, age, marital status or income has an impact towards purchase intention of smartphone among office staff in the North of Vietnam.

\subsection{Reliability Test}

In this section, Cronbach's alpha coefficient is used to test the internal reliability of the items used in the study. Cronbach's alpha reliability coefficient normally ranges between 0 and 1. If the value of Cronbach's alpha coefficient closer to 1.0, it means that the greater the internal consistency of the items in the scale. In this study, six reliability tests were separately conducted, including the five reliability tests (price, brand, design, quality and feature) and purchase intention. The reliability analysis results are shown in Table 2.

Table 2. Reliability Analysis Test for Dependent and Independent Variables

\begin{tabular}{|c|c|c|c|}
\hline Factor & No. of items & $\begin{array}{l}\text { Corrected } \\
\text { Item-total } \\
\text { Correlation }\end{array}$ & Cronbach's Alpha \\
\hline Price & 4 & $\begin{array}{l}0.656 \\
0.626 \\
0.674 \\
0.602\end{array}$ & 0.818 \\
\hline Brand & 5 & $\begin{array}{l}0.495 \\
0.633 \\
0.532 \\
0.490 \\
0.448\end{array}$ & 0.751 \\
\hline Design & 4 & $\begin{array}{l}0.634 \\
0.753 \\
0.608 \\
0.516\end{array}$ & 0.808 \\
\hline Quality & 3 & $\begin{array}{l}0.640 \\
0.618 \\
0.529\end{array}$ & 0.763 \\
\hline Feature & 3 & $\begin{array}{l}0.660 \\
0.801 \\
0.693\end{array}$ & 0.847 \\
\hline Purchase intention & 3 & $\begin{array}{l}0.663 \\
0.697 \\
0.701\end{array}$ & 0.828 \\
\hline
\end{tabular}

It can be clearly seen that all 22 items used in this study obtained Cronbach's alpha value is over 0.751 . This indicates that all questions for the independent and dependent variables are standardized and can be accepted as refer to the rules of thumb about Cronbach's alpha coefficient (Nunnally \& Bernstein, 1994). The Cronbach's alpha of 3 items measuring product feature is 0.847 which is highest as compared to other variables used in the study. The second highest value of Cronbach's alpha is 0.828 which used to measure purchase intention with 3 items. Next, the 4 items measuring product price recorded at 0.818 for Cronbach's alpha. Meanwhile, the Cronbach's alpha value for the product design and quality is 0.808 and 0.763 , respectively. The lowest value of Cronbach's alpha is 0.751 which obtained by brand name with total. It can be concluded that all 22 items used in this study is appropriate.

\subsection{Correlation analysis}

In this subsection, a correlation analysis method is applied to examine the relationships between independent variables and dependent variables. The result of Person Correlation Analysis is showed at Table 3. 
Table 3. Pearson's correlation between variables

\begin{tabular}{lccc}
\hline & Dependent Variable: Purchase intention (PI) & \\
\hline Factor & Pearson Correlation & Sig. & $\mathrm{N}$ \\
Price (PP) & $.744^{* *}$ & .000 & 163 \\
Brand (BN) & $.200^{*}$ & .011 & 163 \\
Design (PD) & $.374^{* *}$ & .000 & 163 \\
Quality (PQ) & $.452^{* *}$ & .000 & 163 \\
Feature (PF) & $.329 * *$ & .000 & 163 \\
\hline
\end{tabular}

Legend: **. Correlation is significant at the 0.01 level (2-tailed).

*. Correlation is significant at the 0.05 level (2-tailed).

The PP variable has the greatest correlation with dependent variable (PI) with Pearson Correlation value $=$ 0.744 , sig $=0.000$, followed by PQ with Pearson Correlation value $=0.452$, sig $=0.000$; whereas $P D$ with Pearson Correlation value $=0.374$, sig $=0.000$ and $\mathrm{PF}$ with Pearson Correlation value $=0.329$, sig $=0.000$, respectively. Finally, BN with Pearson Correlation value $=200$, sig $=0.011$. Based on the obtained results, we can measure the effect level of each independent variable (PP, BN, PD, PQ and PF) with dependent variable (PI), as follows:

In summary, this results shows that there is a significant relationship between PP, BN, PD, PQ and PF towards PI of smartphone. The result demonstrated that the strength of association between independent variables and dependent variable was weak.

\section{Conclusion}

The aim of this study is to find out the elements affecting smartphone purchase intention of office staffs in the North of Vietnam. Five influencing elements are considered, including are price, brand, design, quality, and feature. Then, we discuss about how these elements affect purchase intention of office staffs. Based on the survey results, it can be concluded that a large number of office staffs use smartphone in working and relax.

By using descriptive analysis, we can see clearly, most of office staffs in the North of Vietnam using smartphone is male with $64 \%$, in which there were more single consumers than married consumers, and it took $56 \%$. Based on respondent's age result, the great number of consumers using smartphone is in-group from 22 to 30 years old, it is up to $47 \%$. The office staffs with income from 3.000.000 to 4.000.000 VND per a month is the largest with $45 \%$.

To test the reliability of the items used in the study, we used Cronbach's alpha system and factor analysis. all 22 items used in this study obtained Cronbach's alpha value is over 0.751 , demonstrates the reliability of the used items.

However, the most important contribution of this paper is to provides some of implications that may be useful for businesses and manufactures increase consumer of smartphone among office staffs in the North in Vietnam. Nowadays, the aspiration of office staffs and other consumers is to own a smartphone with famous brand, low price, nice design, good quality and specific feature. This helps the smartphone companies to make further improvements to increase the sales of their products. According to the obtain results from the proposed correlation analysis, the product price has the highest significant impact to smartphone purchase intention of office staffs in the North of Vietnam. Therefore, the business strategies of the companies should be decrease the product price. In addition, a famous smartphone brand should be taken care because there are many consumers think that a brand name is more famous, their quality products is higher.

Besides, the results also show the product image has the significantly impact on purchase intention of smartphone among office staffs in the North of Vietnam. Therefore, the smartphone companies can focus on designing the beautiful models of smartphone, such as the size, shape, button placement, color.

Similarly, product features of a smartphone have the significantly impact on the purchase intention of smartphone among office staffs in the North of Vietnam. Some features of smartphones nowadays, such as wireless connectivity, a built-in web browser, application installation, full programmability, can meet with consumers' needs and desires.

In conclusion, the present research helps us to understand the importance of product features, quality, image, price and brand name, influence on purchase intention of smartphone among office staffs in the North of Vietnam. Future studies need to be carried out to investigate other factors which may influence purchase intention of smartphone. In sum, the results of this study suggested that it is very importance for the smartphone manufacturers to understand what determinants influencing office staffs' purchase intention towards smartphone because they represented the future main uses of smartphone. Moreover, it is the key to increase their own market share within the respective market segment.

\section{References}

[1] Aaker, D.A., and John, G. M. (1989). Image and Competitive Position. Advertising Management. PrenticeHall of India Pve. Ltd., 124-154. 
[2] Aaker, D.A., and Gray, J. S. (1982). Positioning Your Product. Business Horizons.

[3] Agárdi, Irma - András Bauer (2000). Az élelmiszer-kiskereskedelem szerkezeti változásai és kialakult vállalatcsoportok Magyarországon. Marketing \& Menedzsment, 3, 8-14.

[4] Baker, D. A., Crompton, J. L. (2000). Quality satisfaction and behavioral intentions. Annals of Tourism Research, 27(3), 785-804.

[5] Cornelis, P. (2010). Effect of co-branding in the theme park industry: a preliminary study. International Journal and Contemporary Hospitality Management, 22(6), 775-796.

[6] Dodds, W., and Monroe, K. B. (1985). The effect of brand and price information on subjective product evaluations. Advance in Consumer Research, E.C. Hirschman and M.B Holbrook, eds. Provo, UT: Association for Consumer Research, 2, 85-90.

[7] Fandos, C., Flavian, C., (2006). Intrinsic and extrinsic quality attributes, loyalty and buying intention: an analysis for a PDO product. British food journal, 108(8), 646-662.

[ 8] Ghosh, A. (1990). Retail management. Chicago: Drydden press.

[9] Hakoama, M. and Hakoyama, S., (2011). The impact of cell phone use on social networking and development among college students. The AABSS Journal, 15 (2011), 1-20.

[10] Hair, J.F., Bush, R.P., and Ortinau, D.J (2009). Marketing research: In a digital information environment, $312,322,370$.

[11] Keller, K. L. (1993). Conceptualizing, measuring, and managing customer-based brand equity. Journal of Marketing, 57, 1-22.

[12] Kim J. O. and Jin B.H (2001). Korean consumers' patronage of discount stores: Domestic vs. multinational discount stored shoppers' profile. Journal of Consumer Marketing, 18(3), 236-255.

[13] Knight, G. A. and Calantone, R. J. (2000). A flexible model of consumer country-of-origin perceptions. International Marketing Review, 17(2), 127-145.

[14] Kotler, P., \& Armstrong, G. (2007). Principles of Marketing (12th ed.). Boston: Pearson Education.

[15] Kushchu, I., (2007). Positive contributions of mobile phones to society. A Research Report for the Mobile Society Research Institute. UK: Mobile Government Consortium International.

[16] Lay-Yee, K.L., Kok-Siew, H., and Yin-Fah, B.J. (2013). Factors affecting smartphone purchase decision among Malaysian Generation Y. International Journal of Asian Social Science, 3(12), 2426-2440.

[17] Laroche, M., Papadopoulos, N., Heslop, L. A., and Mourali, M. (2005). The influence of country image structure on consumer evaluations of foreign products. International Marketing Review, 22(1), 96-115.

[18] Ling C., Hwang W. and Salvendy G. (2006). Diversified users' satisfaction with advanced mobile phone features. Universal Access in the Information Society, 5(2), 239-249.

[19] Malhotra, N.K. and Peterson, M. (2006). Basic marketing research: A decision-making approach (2nd Ed.). New Jersey: Prentice Hall.

[ 20] Oulasvirta, A., Wahlstrom, M. and Ericsson K. A. (2011). What does it mean to be good at using mobile device? An investigation of three levels of experience and skill. International Journal of Human-Computer Studies, 69, 155-169.

[21] Pavlou, P.A., and Gefen, D (2004). Building effective online market places with institution-based trust. Information Systems Research,15 (1), 37-59.

[22] Sekaran, U. (2003). Research methods for business: A skill building approach (4th ed.). New York: John Wiley \& Sons, Inc.

[23] Whitlar, D.B., Geurts, M.D., Swenson, M.J., (1993). New product forecasting with a purchase intention survey. The Journal of Business Forecasting Methods Systems and Systems, 12, 1-18.

[24] Zeithaml, V.A (1988). Consumer perceptions of price, quality and value: a means-end model and synthesis of evidence. Journal of Marketing, 52(3), 48-62. 